\title{
Soil magnetism, an approach for examining archaeological landscapes
}

\author{
Rinita A. Dalan \\ Office of Contract Archaeology, Southern Illinois University at Edwardsville
}

\author{
Subir K. Banerjee \\ Institute for Rock Magnetism, University of Minnesota, Minneapolis
}

\begin{abstract}
To investigate archaeological landscapes and the extent to which humans have influenced them, we have developed an innovative approach that employs complementary geophysical methods drawn from the fields of exploration geophysics and soil magnetism. Integrating soil magnetic techniques with exploration surveys and more standard archaeological procedures (i.e., topographic mapping, excavation, coring, and soil-chemical studies) at the Cahokıa Mounds site has helped us to better understand the formation of this premier North American mound center and has also demonstrated a scientific methodology of great potential for subsurface investigations of archaeological terrains.
\end{abstract}

\section{Introduction}

The Cahokia Mounds State Historic site represents by far the largest and most complex of the Mississippian period ( $c a$. A.D. 1000-1400) mound centers found across the Eastern Woodlands of the United States (Fowler, 1989; Milner 1990). Located within the Mississippi River flood plain in southwestern Illinois (U.S.A.), the site covers at least $14 \mathrm{~km}^{2}$ and contains the remains of more than 100 mounds. The largest of these mounds is Monks Mound, measuring approximately $291 \times 236 \mathrm{~m}$ at its base and rising to a height of about $30 \mathrm{~m}$ (Skele, 1988). Though the mounds and open borrows documented at the site are indeed impressive, our appreciation of Cahokia and other Mississippian sites has been hampered by a perception of the cultural landscape that has emphasized only such visible above-surface features. Recent research at the Cahokia, site (Dalan, 1993a) using geophysical surveys and soil magnetic techniques, has demonstrated that this perception is misleading and incomplete. Native Americans not only constructed mounds, but, as we can now see with the aid of geophysical methods, they also reworked the landscape by filling and levelling large expanses of ground between the mounds.

\section{Exploration Surveys}

Electromagnetic conductivity and electrical resistivity surveys were applied at Cahokia as a first step in obtaining subsurface information on landscape remolding. Our work concentrated on the Grand Plaza, a broad, flat, open space around which many of the major mounds are grouped

Copyright 1996 by the American Geophysical Union.

Paper number 95GL03689

0094-8534/96/95GL-03689\$03.00
(Fowler, 1989). An electromagnetic conductivity survey (Figure 1) allowed us to define the pre-occupation ridge-swale topography in this area of the site (Dalan, 1991). A northwest-southeast trending band of low-conductivity values (averaging $5-10 \mathrm{mS} / \mathrm{m}$ ) corresponds to a buried sand ridge whose presence was confirmed by test excavations and coring (Holley et al., 1993). Higher conductivity values to the northeast and southwest of the ridge represent swales, containing primarily silts and clays. Conductivity values increase rapidly over a $20 \mathrm{~m}$ wide area adjacent to the northeastern edge of this feature, indicating that the sand ridge has a relatively steep northeastern face in contrast to a broadly sloping southern tail.

The EM conductivity survey also targeted major anthropogenic modifications to the pre-occupation landscape including several previously undiscovered refilled borrows located adjacent to mounds (Dalan, 1991; Holley et al., 1993). Mounds produce significant conductivity anomalies, with the magnitude and character of these anomalies dependent on mound elevation, fill types, and substrate materials.

\section{Soil Magnetic Analyses}

Within natural systems, magnetic techniques have proven to be powerful tools for investigating processes of landscape change (Dearing et al., 1985; Maher, 1986; Thompson and Oldfield, 1986). Variations in magnetic mineralogy, concentration, and/or grain size can also be employed to identify soil movement and sources within cultural systems (i.e., archaeological sites). At Cahokia, we employed soil magnetic methods to detail the extent and character of cultural modifications indicated by exploration surveys and to trace the movement of soils across the Cahokia site that occurred as part of earthmoving efforts (Dalan, 1993a).

Soils at Cahokia are magnetically enhanced due both to pedogenic and cultural processes (Le Borgne, 1965; Maher, 1988; Maher and Taylor, 1988; Mullins, 1974; Taylor et al., 1987; Tite and Mullins, 1971). Cores taken from natural (undisturbed) as well as culturally modified areas display pedogenic enhancement of surface layers below which ARM and $\mathbf{X}$ decrease and stabilize. Surficial $X$ enhancement in undisturbed profiles is generally around two times that of the lower horizons and is limited to approximately the top $25 \mathrm{~cm}$ (the plow zone). The recent age of these flood plain soils (less than 5,000 years old) accounts for the relatively low levels of enhancement observed. Although cores obtained from culturally modified areas also display a drop in X and ARM below the top $25 \mathrm{~cm}$, the values in the upper horizons are generally greater than those observed in natural profiles, and, they remain relatively high to greater depths (through the fill or disturbed zones). Cultural impact was confirmed by soil mor- 


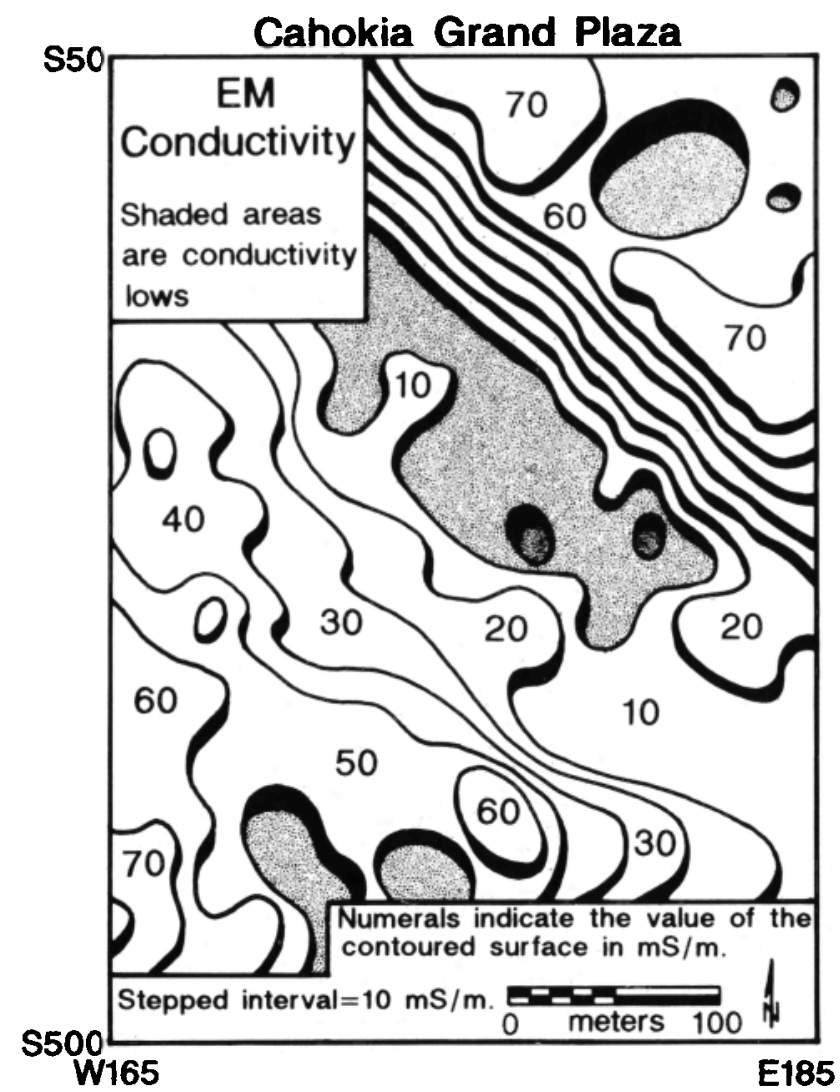

Figure 1. Unclassed three-dimensional conductivity contour map of the Grand Plaza at Cahokia (modified from one produced using the Golden Software surfer program, version 4.07) Apparent conductivities were measured using an EM31D non-contacting terrain conductivity meter (McNeill, 1980). This instrument has an effective penetration depth of approximately $6 \mathrm{~m}$. A total of 12 north-to-south and 10 east-to-west transects were completed over this area, with conductivities recorded every $2 \mathrm{~m}$ along all transects.

phologic analyses as part of test excavations (Holley et al., 1993) and through soil-chemical studies (Dalan, 1993a), such as the analysis of total phosphorous, which may also be used as a cultural indicator. Magnetic properties also vary according to a soil's geomorphologic position on the landscape (e.g., ridge or swale soil).

The principal soil magnetic technique employed at Cahokia was the $A R M / X$ method. Low field susceptibility $(X)$ was measured on a Bartington Instruments MS-1 susceptibility bridge. Anhysteretic Remanent Magnetization (ARM) was acquired by smoothly decreasing an alternating field from a peak value of 9900 Oe to zero in the presence of a small (1 Oe) direct field bias. We plot ARM against $\mathrm{X}$ as a rapid means of characterizing the relative grain sizes and concentrations of the magnetic minerals contained within measured samples (Banerjee et al., 1981; King et al., 1982). Measurement time for both parameters is less than 2 minutes per sample. The application of this method to samples of known affiliation collected from below the plow zone at the Cahokia site shows that natural clayey swale soils and sand ridge soils (within a single meander system) can be distinguished from each other and from both culturally produced soils (i.e., midden) and soils modified, mixed, and transported by the Cahokians (i.e., cultural fill) based on changes in magnetite concentration and grain size (Figure 2).

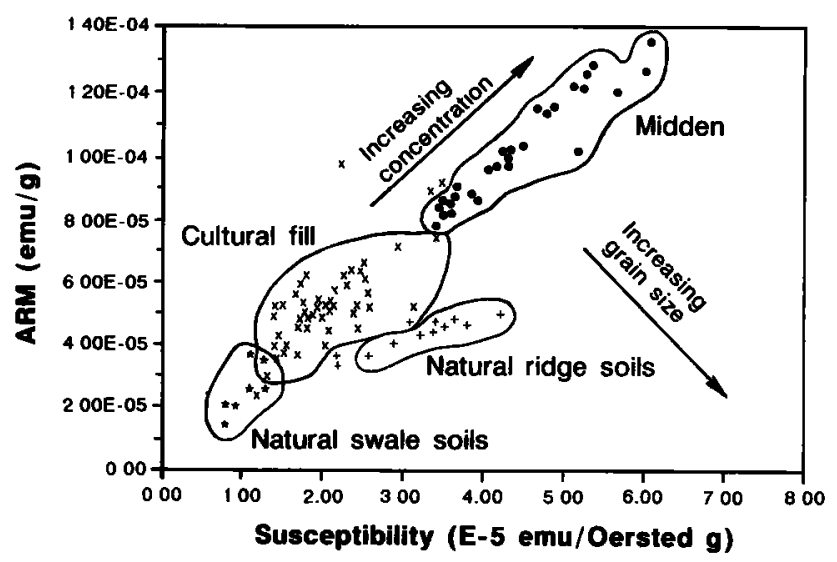

Figure 2. $A R M / X$ model of various soils from the Cahokia site showing relative variations in magnetic concentration and grain size ( $n=48,28,12$, and 7 for the fill, midden, sand, and swale soils, respectively). Changes in the slope of a line fit to plotted samples indicates relative grain-size variations; increasing distance from the origin along such a line represents an increase in concentration.

Saturation in direct magnetic fields of less than $3000 \mathrm{Oe}$, "S" values approximately equal to 1 (Thompson and Oldfield, 1986), and Curie points ranging from 537 to $570^{\circ} \mathrm{C}$ confirmed that magnetite containing small impurities is the dominant magnetic mineral in all soils. Even though the Cahokia soils do contain a significant proportion of paramagnetic material, this does not affect the general interpretation of grain-size relationships derived from the ARM vs. $X$ model. Although replacing $\mathrm{X}$ with paramagnetically corrected $\mathrm{X}\left(\mathrm{X}-\mathrm{X}_{\mathrm{p}}\right)$ values (derived from hysteresis loops) laterally shifts all samples to the left (with the clays, cultural fills, and midden more strongly affected than the natural sands), this correction still positions the natural swale soils, the cultural fills, and the midden along approximately the same line of slope and leaves the coarser-grained sands along a line of lower slope, therefore maintaining all significant relationships of grain size and concentration.

For confirmation of the relative changes in concentration and grain size indicated by the ARM vs, $\mathrm{X}$ model, magnetic hysteresis parameters were measured (Table 1). Saturation remanence and saturation magnetization values verify that the lowest mean concentrations of magnetite are found in the natural swale soils and increasingly higher concentrations are found in the cultural fill, sand ridge soils, and midden. Computed average percentages of magnetite range from 0.005 for the swale soils, to $0.02-0.03$ for the fill and sand ridge soils, to 0.06 for the midden. The use of saturation ratio $\left(\mathrm{J}_{\mathrm{r}} / \mathrm{J}_{\mathrm{v}}\right)$ against coercivity ratio $\left(\mathrm{H}_{\mathrm{cr}} / \mathrm{H}_{\mathrm{c}}\right)$ plots (Day et al., 1977) indicates that

Table 1. Mean values of hysteresis parameters for the various soil types indicated by the ARM/X model.

\begin{tabular}{|c|c|c|c|c|c|}
\hline & 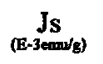 & $\underset{(\mathrm{E}-3 \mathrm{-3}}{\mathrm{J} \text { end/g) }}$ & $\mathrm{Jrs} / \mathrm{Js}_{\mathrm{s}}$ & $\mathrm{Hcr} / \mathrm{Hc}$ & $\mathbf{N}$ \\
\hline swale & 4.91 & 0.74 & 0.16 & 3.47 & 14 \\
\hline fill & 19.47 & 2.22 & 0.12 & 3.76 & 31 \\
\hline midden & 57.30 & 7.75 & 0.14 & 3.32 & 2 \\
\hline ridge & 29.57 & 2.65 & 0.09 & 4.43 & 9 \\
\hline
\end{tabular}


the average grain size of the magnetite falls across the PSDMD boundary (10-20 $\mu \mathrm{m})$, with the larger-grained sand ridge soils consistently plotting beyond the MD boundary.

On the basis of the magnetic data, it was proposed that the cultural fill was produced through the admixture of similarlysized midden and natural swale soils. The sand ridge soils, as they are coarser-grained, can not be a principal component of the cultural fill. Thus, the concentration line on the ARM/X diagram (extending from the swale soils through the fill to the midden) actually represents a mixing line, with the distance from the origin reflecting the amount of midden added during prehistoric land reclamation. A mixing model (Stott, 1986; Yu and Oldfield, 1989), based on parameters expressive of magnetite concentration, was advanced to determine the proportional contributions of the proposed sources. It was assumed that mixing was mechanical, that magnetic properties remained constant, and that only minor pedogenic enrichment would have occurred following deposition. Estimates using high-field párameters $\left(J_{g}\right.$ and $\left.J_{n}\right)$ (Table 1), considered most useful as these reflect only the ferrimagnetic component and are less dependent on grain size than are low-field parameters, indicate that mixing approximately one part midden and three parts swale soils would produce the average concentrations of magnetic minerals noted in the cultural fill. The model of cultural mixing was confirmed by soil-chemical, soil-morphological, and archaeological evidence (Dalan, 1993a).

Applying the ARM/X model to over 900 samples derived from 36 core locations within the Grand Plaza detailed culturally modified areas of the landscape within this important central region of the site including a laterally-extensive area ( $>$ $37,000 \mathrm{~m}^{2}$ ) of borrowed and reclaimed ground (Figure 3). Located within the northern swale, this lateral borrow was not indicated by the electromagnetic conductivity survey (Figure 1). With a depth of slightly over one meter, and limits extending beyond the study area both to the north and to the east, this borrow represents a massive earthmoving project that is not indicated by surface inspection. Borrowing was probably directed toward obtaining soils for the erection of a basal platform for Monks Mound (located due north of the Grand Plaza) (Holley et al., 1993). The borrowed ground was then reclaimed using various types of fill. The earliest fill stages consist of more heterogeneous deposits that contain a greater quantity of midden derived from habitation areas to the north of the Grand Plaza. Later fill deposits are more homogeneous and contain more natural clayey soils, and thus are interpreted as being directed toward elevating the area to create a clean and level plaza surface. Dated by ceramics recovered through test excavations (Holley et al., 1993), this feature provides critical evidence for large scale landscape-modifying activities commencing late within the Emergent Mississippian period (A.D. 950-1000) and for the early formation (ca. A.D. 10001050) of a site center that included not only a principal mound (i.e., Monks Mound) (Fowler, 1989; Reed et al., 1968) but also a Grand Plaza complex. Also using techniques of $\mathrm{ARM} / \mathrm{X}$ and magnetic hysteresis, variability in the composition and structure of mounds located within the Grand Plaza (Figure 3), first suggested by the electromagnetic survey, was investigated as was the integrity of submound deposits and the nature and extent of reclaimed borrows located next to mounds (Dalan, 1993a). Combining this data with that arrived at using more traditional archaeological methods provides a new appreciation of the nature, scale, and dynamics of landscape change at Cahokia (Dalan, in press), and allows us to begin to explain why the volume of open borrows mapped

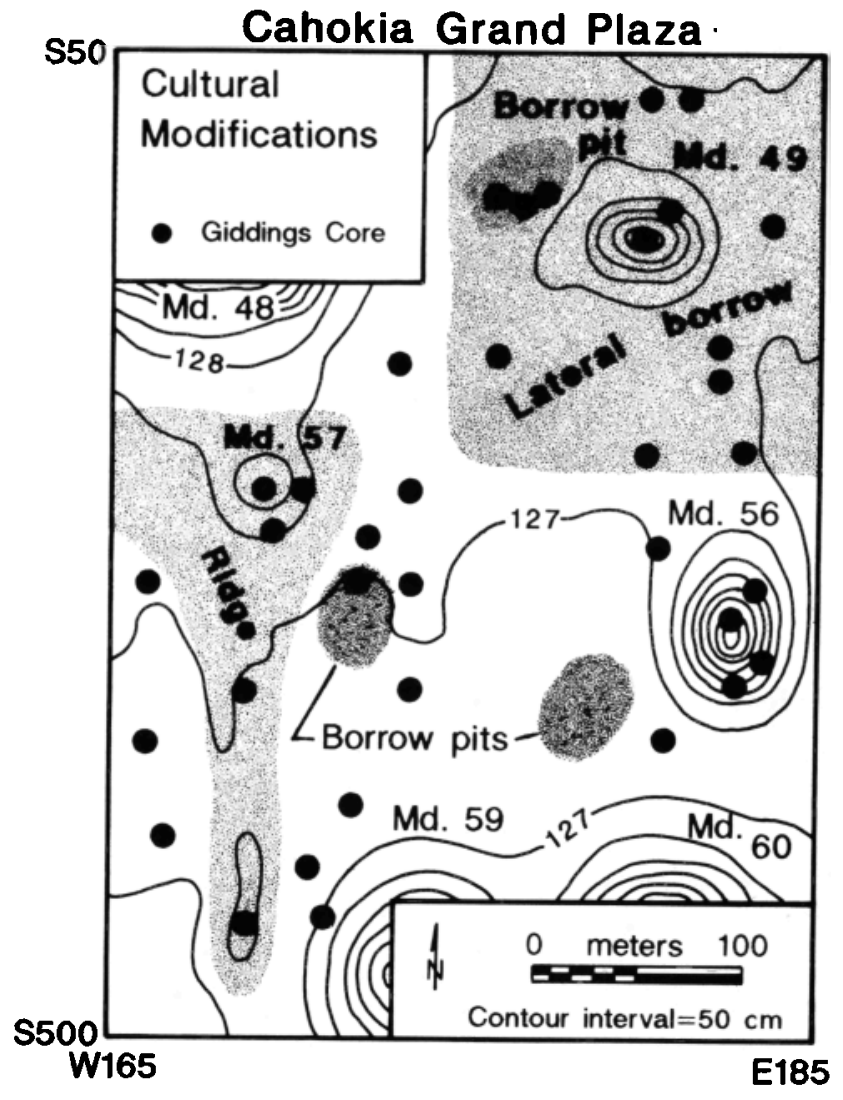

Figure 3. Topographic map of the Grand Plaza, showing cultural modifications of the terrain, as defined by rock magnetic studies of 36 cores. Mounds are obvious as elevations rising above the level surface (mounds $48,49,56,57,59$, and $60)$.

at the site (Fowler, 1989) does not nearly approach the volume of known mounds.

\section{Conclusions}

On the basis of the Cahokia results, broader application of this package of methods to the difficult problem of studying archaeological landscapes (Deetz, 1990) is warranted. Although exploration surveys have a relatively long history of use in archaeological research (Clark, 1990; Scollar et al., 1990; Weymouth, 1986), soil magnetic techniques have not yet found wide use in the discipline. We have shown, however, that magnetic techniques can be particularly effective for identifying anthropogenically modified soils and for tracking the movement of soils over a site due to cultural processes. When applied in conjunction with more traditional methods at Cahokia, we have been able to look beyond surface expressions of earthmoving activities to include subsurface evidence for borrowing, levelling, and reclaiming. A more comprehensive and diachronic picture of the growth of the site has resulted. Employing both exploration and laboratory geophysical techniques allows us to investigate landscape features at a wide range of scales (Dalan, 1993b) and to cover relatively large sections of the landscape (such as the Grand Plaza at Cahokia) in a relatively nondestructive, rapid, and inexpensive manner. The advantage of using ARM/X plots to provide information on magnetic granulometry and concentration is that this technique allows large quantities of material to be analyzed (greater than 1350 samples were measured from 
Cahokia) and it may also provide finer scale resolution of grain size variation with much less effort than hysteresis loops. Likewise, ARM/X plots can be used to identify cultural soils much faster (and much less destructively) than test excavations or soil-chemical analyses.

Acknowledgements. We thank personnel at the following agencies for their assistance with this project: the Illinois Historic Preservation Agency; the Cahokia Mounds State Historic Site; the Cahokia Mounds Museum Society; the Soil Conservation Service; the Contract Archaeology Program, Southem Illinois University at Edwardsville; and the Institute for Rock Magnetism, University of Minnesota. The Institute for Rock Magnetism is supported by the USNSF and the W.M. Keck Foundation (Los Angeles). Harold W. Watters, Jr., prepared the figures used in this manuscript. This research was supported through fellowships awarded by the American Society for Photogrammetry and Remote Sensing, the Society of Exploration Geophysicists, and the University of Minnesota.

\section{References}

Banerjee, S.K., J.W. King, and J.A. Marvin, A rapid method for magnetic granulometry with application to environmental studies, Geophys. Res. Lett., 8, 333-336, 1981.

Clark, A.J., Seeing Beneath the Soil: Prospecting Methods in Archaeology, 176 pp., B.T. Batsford, London, 1990.

Dalan, R.A., Defining archaeological features with electromagnetic surveys at the Cahokia Mounds State Historic Site, Geophysics, 56, 1280-1287, 1991.

Dalan, R.A., Landscape modification at the Cahokia Mounds Site: Geophysical evidence of culture change, Ph.D. thesis, 238 pp., University of Minnesota, 1993a.

Dalan, R.A., Issues of scale in archaeogeophysical research, in Effects of Scale in Archaeological and Geoscientific Perspectives, edited by J.K. Stein and A. Linse, pp. 67-78, Geological Society of America, Boulder, Colorado, $1993 \mathrm{~b}$.

Dalan, R.A., The construction of Mississippian Cahokia, in Domination and Ideology in the Mississippian World, edited by $\mathrm{T}$. Pauketat and T. Emerson, Chapter 7, University of Nebraska Press, Lincoln, in press.

Day, R., M. Fuller, and V.A. Schmidt, Hysteresis properties of titanomagnetites: Grain size and compositional dependence, Phys. Earth Planet. Inter., 13, 260-277, 1977.

Dearing, J.A., B.A. Maher, and F. Oldfield, Geomorphological linkages between soils and sediments: The role of magnetic measurements, in Geomorphology and Soils, edited by K.S. Richards, R.R. Amett, and S. Ellis, pp. 245-266, Allen and Unwin, London, 1985.

Deetz, J., Prologue: Landscapes as cultural statements, in Earth Patterns: Essays in Landscape Archaeology, edited by W.M. Kelso and R. Most, pp. 1-4, University Press of Virginia, Charlottesville, 1990.

Fowler, M.L., The Cahokia Atlas: A Historical Atlas of Cahokia Archaeology, 245 pp., Illinois Historic Preservation Agency, Springfield, 1989.

Holley, G.R., R.A. Dalan, and P.A. Smith, Investigations in the Cahokia Site Grand Plaza, Am. Antiq., 58, 306-319, 1993.
King, J.W., S.K. Banerjee, J. Marvin, and Ö. Özdemir, A comparison of different magnetic methods for determining the relative grain sizes of magnetite in natural materials: Some results in lake sediments, Earth Planet. Sci. Lett., 59, 404-419, 1982.

Le Borgne, E., Les Propriétes magnétiques du sol. Application à la prospection des sites archéologiques, Archaeo-Physika, 1, 1-20 1965.

McNeill, J.D., Electromagnetic Terrain Conductivity Measurement at Low Induction Numbers, Tech. Note TN-6, 15 pp., Geonics Limited, Mississauga, Ontario, 1980.

Maher, B.A., Characterisation of soils by mineral magnetic measurements, Phys. Earth Planet. Inter., 42, 76-92, 1986.

Maher, B.A., Magnetic properties of some synthetic submicron magnetites, Geophys. J., 94, 83-96, 1988.

Maher, B.A., and R.M. Taylor, Formation of ultra fine-grained magnetite in soils, Nature, 336, 368-371, 1988.

Milner, G.R., The late prehistoric Cahokia cultural system of the Mississippi River Valley: foundations, florescence, and fragmentation, J. World Prehistory, 4, 1-43, 1990.

Mullins, C.E., The magnetic properties of the soil and their application to archaeological prospecting, Archaeo-Physika, 5, 143-347, 1974.

Reed, N.A., J.W. Bennett, and J.W. Porter, Solid core drilling of Monks Mound: Technique and findings, Am. Antiq., 33, 137-148, 1968

Scollar, I., A. Tabbagh, A. Hesse, and I. Herzog, Archaeological Prospecting and Remote Sensing, 636 pp., Cambridge University Press, Cambridge, 1990.

Skele, M., The Great Knob: Interpretations of Monks Mound, 112 pp., Illinois Historic Preservation Agency, Springfield, 1988.

Stott, A.P., Sediment tracing in a reservoir-catchment system using a magnetic mixing model, Phys. Earth Planet. Inter., 42, 105-112, 1986.

Taylor, R.M., B.A. Maher, and P.G. Self, Magnetite in soils: The synthesis of single-domain and superparamagnetic magnetite, Clay Min., 22, 411-422, 1987.

Thompson, R., and F. Oldfield, Environmental Magnetism, 227 pp. Allen and Unwin, London, 1986.

Tite, M.S., and C.E. Mullins, Enhancement of the magnetic susceptibility of soil on archaeological sites, Archaeometry, 13, 209-219, 1971 .

Weymouth, J.W., Geophysical methods of archaeological site surveying, In Advances in Archaeological Method and Theory, vol. 9, edited by M.B. Schiffer, pp. 311-395, Academic Press, New York, 1986

$\mathrm{Yu}$, L. and F. Oldfield, A multivariate mixing model for identifying sediment source from magnetic measurements, Quat. Res., 32, 168-181, 1989.

S.K. Banerjee, Institute for Rock Magnetism, 293 Shepherd Laboratories, 100 Union Street S.E., University of Minnesota, Minneapolis, MN 55455.

R.A. Dalan, Office of Contract Archaeology, Box 1458, Southern Illinois University at Edwardsville, Edwardsville, IL 62026

(Received September 19, 1995; revised November 27, 1995; accepted December 2, 1995) 